\title{
A Study on the Improvement of Learning Outcome of University Students: Focusing on majoring in Social Welfare
}

\author{
JooYoung Jung ${ }^{1}$ and Yujin $\operatorname{Im}^{2 *}$ \\ Assistant Professor, Kosin University, Busan, South Korea \\ ljyjung@kosin.ac.kr, ${ }^{2} y j i m @ k o s i n . a c . k r$
}

\begin{abstract}
In order to seek for the measures for the improvement of learning outcome of university students majoring in social welfare of Korea, this study analyzed the relations of learning outcome, satisfaction (major education, interaction with professors, learning support service of university), perception of cooperative learning activity. For this, out of the data of

'National Assessment of Student Engagement in Learning (NASEL)」 in 2015, total 776 were selected, and then the multiple regression analysis was conducted. In the results of analysis, participated in the community volunteer activities as a part of lesson, judged their own learning outcome as high. And the students who performed the cooperative learning activities like actively sharing opinions with other people and seeking for solutions to problems during class hours and non-class hours, judged their learning outcome as high, compared to other students. Also, the students who frequently met and discussed with professors for the matter of career or not, and also used the mentoring service for the adaptation to university life, cognized their learning outcome as high, compared to other students. Based on such results of this study, the measures for the improvement of learning outcome of university students majoring in social welfare were suggested.
\end{abstract}

Keywords: Learning outcome, Satisfaction of major education, Majoring in social welfare

\section{Introduction}

In the past, social welfare education has continued to reflect on and improve the quality of education. Most of the discussions on improving the quality of education were focused on social welfare professions [1], discussions on overall improvement plans for professionalism [2], and reform of the curriculum [3]. However, except for the practical subjects, little learning outcomes were available to assess the quality of social welfare education.

It is important to make sure that such competences as educational outcomes are prepared through education because they are essential for realizing the talent image pursued in social welfare education. In addition, social welfare education should identify the factors that help students' core competencies to provide practical technical education that enriches the competencies of prospective social workers before graduation. The purpose of this study is to investigate the factors influencing the learning outcomes of social welfare students and to find ways to contribute to the improvement of learning effect of social welfare university students.

\section{Background}

Article history:

Received (January 19, 2020), Review Result (February 23, 2020), Accepted (April 2, 2020) 
Learning outcomes are the product of educational outcomes, and can serve as a benchmark for university students to see what they experience and how to grow in university. Many researchers are interested in the factors that improve college student performance. They are based on their personal background, pre-university education and experience, learning experiences at university, university characteristics [4]. The purpose of social welfare is to improve the quality of life by satisfying various needs of people and solving social problems. Therefore, social welfare education seeks to cultivate talented people with the ability to integrate and apply knowledge about complex needs and solutions for human beings [5]. The learning outcomes of university students majoring in social welfare should reflect the realization of talented people who want to cultivate social welfare education and the improvement of core competencies that should be basically provided as university students.

Social welfare studies have a strong characteristic of field-based practical studies because they have an educational curriculum for producing social workers. Properly equipped with theoretical-based academic capacity and the professionalism required in the field grows from general learner to social worker. Social workers are based on human dignity and social justice beliefs, along with individuals, families, groups, organizations, communities and the whole society, and stand on the side of the marginalized and suffering people to protect human rights and interests, It is a person who refuses and puts public interest ahead of individual interests. Regarding the capacities required as social workers, the American Council on Social Welfare Education cited cognitive and interaction or relationship skills. Many previous studies [6] also found that job-based skills such as problem-solving skills, communication skills, and relationship-building skills are necessary for social workers.

\section{Research methods}

\subsection{Research subject}

In order to explore the factors that affect the learning outcomes of social welfare majors, this study uses the 2015 National Assessment of Student Engagement in Learning (NASEL) data from the Korea Educational Development Institute. A total of 48,357 students from 70 universities nationwide participated in the 2015 survey. In this study were selected. a total of 776 people who correctly answered that they were majoring in social welfare and social welfare.

\subsection{Variable and measuring tool}

The data used in this study is a national level test tool to analyze the characteristics and current status of Korean university students' teaching-learning process. Reflecting the results of previous studies on social welfare and college student learning outcomes [4][7], Learning outcomes(dependent variable) consisted of eight items including major competence and expertise, higher-order thinking ability, communication, and cooperation ability. Independent variables consisted of five major factors: participation in clubs and volunteer activities (4 items), collaborative learning activities (4 items), interaction with professors (5 items), major education satisfaction (11 items), and academic support services (3 items).

\subsection{Analytical method}

In this study, frequency and multiple regression analyzes were conducted to examine the effects of independent variables (Learning outcomes, major educational satisfaction, 
interaction with professors, university learning support services, participation in clubs and volunteer activities, collaborative learning activities, active learning activities) on dependent variables (Learning achievement). The analysis utilized the SPSS 21.0 program.

\section{Research results}

\subsection{Main variables' characteristic}

Among the survey subjects, 534(68.8\%) female students and 242 (31.2\%) male students, 462 (59.5\%) Occasional admission, 280 (36.1\%) Regular admission, 34 (4.4\%) the other admissions. $661(85.2 \%)$ non-metropolitan universities students, 115 (14.8\%) metropolitan universities students. 417 (53.7\%) small and medium-sized universities students and 359 (46.3\%) large universities students. Major competencies and knowledge scored highest among the learning outcomes (dependent variable). Among the independent variables, the following items showed the highest scores by area. (Participation in voluntary community service activities, giving and receiving help with students in the same class, explaining the contents of the majors in relation to prior experiences, discussing the contents and tasks with the professors, and tutoring services for learning support). Reliability was high as shown in the table below.

Table 1. Mean of variables

\begin{tabular}{|c|c|c|c|c|c|}
\hline \multicolumn{2}{|c|}{ Variables } & Items & Mean & SD & $\begin{array}{c}\text { Cronbach } \\
{ }^{\alpha} \alpha\end{array}$ \\
\hline \multirow{8}{*}{$\begin{array}{l}\text { Learning } \\
\text { outcomes }\end{array}$} & \multirow{2}{*}{$\begin{array}{c}\text { Major } \\
\text { competency } \\
\text { expertise }\end{array}$} & Class or work related knowledge and skills & 2.60 & .789 & \multirow{2}{*}{.865} \\
\hline & & Knowledge and skills related to the major field & 2.73 & .798 & \\
\hline & \multirow{3}{*}{$\begin{array}{c}\text { Higher-order } \\
\text { Thinking } \\
\text { ability }\end{array}$} & Critical, analytical thinking & 2.39 & .871 & \multirow{3}{*}{.868} \\
\hline & & Problem-solving ability & 2.38 & .814 & \\
\hline & & Creative, convergent thinking & 2.14 & .868 & \\
\hline & \multirow{3}{*}{$\begin{array}{c}\text { Communicat } \\
\text { ion and } \\
\text { cooperation } \\
\text { skills }\end{array}$} & Teamwork and collaboration & 2.59 & .837 & \multirow{3}{*}{.791} \\
\hline & & Ability to understand multiculturalism & 2.26 & .947 & \\
\hline & & Community consciousness & 2.55 & .894 & \\
\hline \multirow{4}{*}{\multicolumn{2}{|c|}{ Club activities }} & Participation in club activities & 2.31 & 1.173 & \multirow{4}{*}{.756} \\
\hline & & $\begin{array}{l}\text { Participation in student body organization and student body } \\
\text { activities }\end{array}$ & 1.74 & 1.040 & \\
\hline & & Volunteering voluntarily, community service & 2.62 & 1.035 & \\
\hline & & $\begin{array}{l}\text { Volunteering, Community Service Participation as part of the } \\
\text { class }\end{array}$ & 2.21 & 1.060 & \\
\hline \multirow{4}{*}{\multicolumn{2}{|c|}{ Collaborative learning }} & Interaction with the same class students for assignments & 3.01 & .832 & \multirow{4}{*}{.722} \\
\hline & & $\begin{array}{l}\text { Interaction with students outside the same class for } \\
\text { Assignments }\end{array}$ & 2.34 & 966 & \\
\hline & & Talking to others about what you have learned & 2.51 & .842 & \\
\hline & & Finding the solution to the problem and explaining it & 2.20 & .864 & \\
\hline \multirow{4}{*}{$\begin{array}{c}\text { Satisfac- } \\
\text { Tion of } \\
\text { Major }\end{array}$} & Instructional & Clear goals and expectations of the class & 2.63 & .793 & \multirow{3}{*}{.772} \\
\hline & goals and & Appropriating amount of learning & 2.51 & .856 & \\
\hline & content & Interesting and stimulates intellectual curios class & 2.53 & .872 & \\
\hline & Learning & Enough time to understand the learning content & 2.43 & .863 & .871 \\
\hline
\end{tabular}


A Study on the Improvement of Learning Outcome of University Students: Focusing on majoring in Social Welfare

\begin{tabular}{|c|c|c|c|c|}
\hline \multirow[t]{4}{*}{ experience } & Class using materials, media & 2.99 & .802 & \\
\hline & Professors whose associate with their major experiences & 3.06 & .802 & \\
\hline & Appropriate cases presentation in relation to the major & 2.86 & .834 & \\
\hline & Additional explanation in case of difficulty in learning & 2.85 & .814 & \\
\hline \multirow{3}{*}{$\begin{array}{l}\text { Learning } \\
\text { assessment } \\
\text { and } \\
\text { feedback }\end{array}$} & Evaluation management and grading fair. & 2.81 & .837 & \multirow{3}{*}{.793} \\
\hline & Appropriate test & 3.01 & .771 & \\
\hline & Faithful feedback from the professor & 2.66 & .881 & \\
\hline \multirow{5}{*}{$\begin{array}{l}\text { Interaction with } \\
\text { Professor }\end{array}$} & Discussion with the professor about the enrollment & 1.40 & .718 & \multirow{5}{*}{.847} \\
\hline & $\begin{array}{l}\text { Discussion with the professor about the contents and tasks of } \\
\text { the class }\end{array}$ & 1.93 & .801 & \\
\hline & Discussion with the professor about the test and the grade & 1.77 & .800 & \\
\hline & Discussion with Professor about career path & 1.83 & .828 & \\
\hline & $\begin{array}{c}\text { Interaction with professor on things other than classes and } \\
\text { career paths }\end{array}$ & 1.65 & .821 & \\
\hline \multirow{3}{*}{$\begin{array}{l}\text { University student } \\
\text { Support Services }\end{array}$} & Teaching and learning support & 3.81 & 1.162 & \multirow{3}{*}{.820} \\
\hline & Tutoring service for learning support & 4.24 & 1.147 & \\
\hline & Mentoring Service for Adaptation to University Life & 4.08 & 1.174 & \\
\hline
\end{tabular}

\subsection{Factors affecting learning outcomes}

As a result of checking multicollinearity to find out the factors that influence social learning and students' learning outcomes, all items were used because VIF value did not exceed 10, and the explanation amount (R) was 41.6\%. In terms of individual factors, 'gender', 'admission' and 'current semester' were statistically significant, which means that male students perceive their learning outcomes to be higher than female students, occasional admission students than regular admission, and higher grade students than lower grade students. In the club and volunteer participation variables, the question of 'Participation in community service as part of the class' was statistically significant. This means that students who are majoring in social welfare at university actively participate in club activities and participate in community service activities as part of their class, and they judge their learning outcomes higher. The cooperative learning activity variables showed statistically significant questions such as "coordinating and receiving help with the same class students for class assignments" and "finding solutions to problems and explaining them to others". This means that students who participate in collaborative learning activities, such as actively communicating with others and finding solutions to problems in class and out of class, value their learning outcomes higher than those who do not.

The university factors were statistically significant in terms of 'discussing with professors about careers', 'discussing with professors outside of classes or careers', and 'mentoring services for adjusting to university life'. This means that students who meet and discuss professors in their careers and those who use mentoring services to adjust to college life will recognize that their learning outcomes are higher than those who do not.

Table 2. Analysis of the impact of independent variables on learning outcomes

\begin{tabular}{|c|c|c|c|c|c|c|c|}
\hline \multirow[t]{2}{*}{ Valuables } & \multirow[t]{2}{*}{ Items } & \multicolumn{2}{|c|}{$\begin{array}{c}\text { Non- } \\
\text { standardized } \\
\text { coefficient }\end{array}$} & $\begin{array}{c}\text { Standardized } \\
\text { coefficient }\end{array}$ & \multirow[t]{2}{*}{$\mathrm{t}$} & \multicolumn{2}{|c|}{ Multicollinearity } \\
\hline & & B & $\mathrm{SE}$ & $\beta$ & & Tolerance & VIF \\
\hline
\end{tabular}




\begin{tabular}{|c|c|c|c|c|c|c|c|}
\hline & & & & & & limit & \\
\hline \multirow{5}{*}{$\begin{array}{l}\text { Personal } \\
\text { Factors }\end{array}$} & Gender & .105 & .042 & .075 & $2.518^{*}$ & .879 & 1.138 \\
\hline & Admission & -.073 & .032 & .065 & $2.256^{*}$ & .937 & 1.068 \\
\hline & Semester & .047 & .016 & .088 & $2.928 * *$ & .865 & 1.157 \\
\hline & Location & .063 & .057 & .035 & 1.099 & .788 & 1.269 \\
\hline & University size & .037 & .041 & .028 & .884 & .767 & 1.303 \\
\hline \multirow{4}{*}{$\begin{array}{l}\text { Club } \\
\text { activities }\end{array}$} & Participation in club activities & .014 & .017 & .025 & .801 & .790 & 1.265 \\
\hline & $\begin{array}{l}\text { Participation in student body organi- } \\
\text { zation and student body activities }\end{array}$ & .013 & .020 & .021 & .640 & .738 & 1.356 \\
\hline & $\begin{array}{c}\begin{array}{c}\text { Volunteering voluntarily, community } \\
\text { service }\end{array} \\
\end{array}$ & .031 & .023 & .049 & 1.354 & .591 & 1.691 \\
\hline & $\begin{array}{l}\text { Volunteering, Community Service } \\
\text { Participation as part ofthe class }\end{array}$ & .048 & .022 & .079 & $2.150^{*}$ & .589 & 1.698 \\
\hline \multirow{4}{*}{$\begin{array}{c}\text { Collaborative } \\
\text { learning }\end{array}$} & $\begin{array}{l}\text { Interaction with the same class } \\
\text { students for assignments }\end{array}$ & .087 & .027 & .112 & $3.224 * *$ & .652 & 1.534 \\
\hline & $\begin{array}{l}\text { Interaction with students outside the } \\
\text { same class forassignments }\end{array}$ & .014 & .023 & .021 & .599 & .645 & 1.549 \\
\hline & $\begin{array}{c}\text { Talking to others about what you have } \\
\text { learned }\end{array}$ & .052 & .029 & .068 & 1.820 & .562 & 1.778 \\
\hline & $\begin{array}{l}\text { Finding the solution to the problem } \\
\text { and explaining it }\end{array}$ & .089 & .030 & .119 & $3.011 * *$ & .501 & 1.995 \\
\hline \multirow{3}{*}{$\begin{array}{l}\text { Instructional } \\
\text { goals and } \\
\text { learning } \\
\text { content }\end{array}$} & $\begin{array}{c}\text { Clear goals and expectations of the } \\
\text { class }\end{array}$ & .037 & .032 & .045 & 1.168 & .520 & 1.924 \\
\hline & Appropriating amount of learning & .025 & .032 & .034 & .797 & .441 & 2.270 \\
\hline & $\begin{array}{l}\text { Interesting and stimulates intellectual } \\
\text { curios class }\end{array}$ & .039 & .032 & .053 & 1.218 & .409 & 2.443 \\
\hline \multirow{5}{*}{$\begin{array}{l}\text { Learning } \\
\text { experience }\end{array}$} & $\begin{array}{l}\text { Enough time to understand the } \\
\text { learning content }\end{array}$ & .021 & .033 & .028 & .649 & .414 & 2.413 \\
\hline & Class using materials, media & .013 & .035 & .016 & .366 & .414 & 2.414 \\
\hline & $\begin{array}{l}\text { Professors whose associate with their } \\
\text { major experiences }\end{array}$ & .007 & .038 & .009 & .183 & .346 & 2.890 \\
\hline & $\begin{array}{l}\text { Appropriate cases presentation in } \\
\text { relation to the major }\end{array}$ & .011 & .035 & .015 & .324 & .389 & 2.570 \\
\hline & $\begin{array}{l}\text { Additional explanation in case of } \\
\text { difficulty in learning }\end{array}$ & .027 & .036 & .034 & .735 & .373 & 2.684 \\
\hline \multirow{3}{*}{$\begin{array}{c}\text { Learning } \\
\text { assessment } \\
\text { and feedback }\end{array}$} & $\begin{array}{l}\text { Evaluation management and grading } \\
\text { fair }\end{array}$ & -.016 & .032 & -.021 & -.500 & .457 & 2.189 \\
\hline & Appropriate test & .022 & .036 & .026 & .603 & .415 & 2.411 \\
\hline & Faithful feedback from the professor & .021 & .032 & .029 & .657 & .414 & 2.416 \\
\hline \multirow{5}{*}{$\begin{array}{l}\text { Interaction } \\
\text { with } \\
\text { Professor }\end{array}$} & $\begin{array}{l}\text { Discussion with the professor about } \\
\text { the enrollment }\end{array}$ & .035 & .036 & .039 & .963 & .486 & 2.059 \\
\hline & $\begin{array}{l}\text { Discussion with the professor about } \\
\text { the contents and tasks of the class }\end{array}$ & .063 & .034 & .079 & 1.866 & .441 & 2.268 \\
\hline & $\begin{array}{l}\text { Discussion with the professor about } \\
\text { the test and the grade }\end{array}$ & .006 & .035 & .007 & .159 & .412 & 2.425 \\
\hline & $\begin{array}{c}\text { Discussion with Professor about career } \\
\text { path }\end{array}$ & .075 & .031 & .096 & $2.432 *$ & .500 & 2.002 \\
\hline & $\begin{array}{l}\text { Interaction with professor on things } \\
\text { other than classes andcareer paths }\end{array}$ & .091 & .030 & .116 & $3.075^{* *}$ & .553 & 1.809 \\
\hline University & Teaching and learning support & -.011 & .020 & -.020 & -.534 & .576 & 1.737 \\
\hline
\end{tabular}


A Study on the Improvement of Learning Outcome of University Students: Focusing on majoring in Social Welfare

\begin{tabular}{|c|c|c|c|c|c|c|c|}
\hline \multirow{2}{*}{$\begin{array}{l}\text { student } \\
\text { Support } \\
\text { Services }\end{array}$} & Tutoring service for learning support & -.003 & .026 & -.006 & -.121 & .376 & 2.662 \\
\hline & $\begin{array}{c}\text { Mentoring Service for Adaptation to } \\
\text { University Life }\end{array}$ & .088 & .023 & .161 & $3.813 * * *$ & .442 & 2.264 \\
\hline \multicolumn{2}{|r|}{ Constant } & .079 & .154 & & .511 & & \\
\hline \multicolumn{8}{|c|}{$\mathrm{R}^{2}=.416$ adj. $\mathrm{R}^{2}=.391 \mathrm{~F}=16.520 * * *$} \\
\hline
\end{tabular}

\section{Conclusion and suggestions}

The purpose of this study is to find out how to improve the learning outcomes of the social welfare department students. As a result of analysis, the students who majored in social welfare at university actively participated in club activities and participated in community service activities as part of the class. In addition, students who participated in collaborative learning activities, such as actively communicating with others and finding solutions to problems in class and out of class, rated their learning outcomes higher than those who did not. Also, the students who meet and discuss professors in their careers and those who use mentoring services to adjust to college life will recognize that their learning outcomes are higher than those who do not. In addition to cognitive achievements such as credits and certifications, non-cognitive achievements such as major competencies, communication skills, problem solving skills, and creativity are essential to enter society after graduation and to interact with many people.

Students who are actively engaged in club activities and community service activities have higher levels of learning outcomes, which is consistent with the results of previous studies [8] that volunteer work as part of class affects the learning outcomes of social welfare university students. In the case of social welfare majors, a rich and innovative service learning should be reflected in the curriculum, as it requires a curriculum that effectively combines theory and practice [9]. It is a good idea to consider clubs that can be opened within the department and encourage active activities. The more collaborative activities, such as actively communicating with others and finding solutions to problems, the higher the learning outcomes. Therefore, it is necessary to adjust the curriculum and methods so that students can collaborate.

\section{References}

[1] H. K. Lee and C. S. Nam, "Fifty years' history of social welfare education in Korea -in the context of institutionalization of social welfare and universalization of higher education," Korean Journal of Social Welfare Education, vol.5, no.1, pp.69-95, (2005)

[2] B. D. Ahn and K. H. Lee, "The influence of major related satisfaction of social welfare students on the professional identity of social welfare," Korean Journal of Social Welfare Education, vol.32, pp.167-184, (2015)

[3] Y. H. Won, J. S. Ahn, and J. H. Bae, "A study on the curriculum development of the social welfare undergraduate program based on social workers competency modeling," Korean Journal of Social Welfare Education, vol.13, pp.149-180, (2010)

[4] E. G. Kim, J. Y. Ahn, H. J. Hwang, and G. H. Kim, "The influence of lecture quality on the learning outcomes of university students: focusing on the moderating effects of student support services," Korean Journal of Educational Administration, vol.35, no.1, pp.169-193, (2017)

[5] H. E. Nam, N. S. Kim, S. H. Kim, Y. J. Im, M. R. Lee, E. S. Bae, J. W. Baik, H. K. Park, J. H. Son, K. H. Youn, and H. Y. Lee, "Recognition of experts on social welfare education in response to changes in future society in South Korea," Korean Journal of Educational Administration, vol.43, pp.55-80, (2018) DOI : 10.31409/KJSWE.2018.43.55 
[6] S. Braye, M. Lebacq, F. Mann, and E. Midwinter, "Learning social work law: an inquiry-based approach to developing knowledge and skills," Social Work Education, vol.22, no.5, pp.479-492, (2003) http:doi.org/10.1080/0261547032000126425

[7] S. M. Park and J. W. Ko, "An analysis of structural relationships among college environment, student engagement and learning outcomes," Korean Journal of Educational Administration, vol.34, no.4, pp.187-213, (2016)

[8] H.Y.Kim, S.Y.Park, and S.J.Lee, "A study on the factors of learning outcomes in higher education : based on the teaching qualities and extracurricular activities," The Journal of Educational Research, vol.15, no.2, pp.1$18,(2017)$

[9] I. Y. Han, H. W. Park, and J. H. Kim, "Implementation of service-learning for social work education," Korean Journal of Social Welfare, vol.57, no.3, pp.251-276, (2005) 
A Study on the Improvement of Learning Outcome of University Students: Focusing on majoring in Social Welfare

This page is empty by intention. 